\title{
Measuring brand equity in banking industry: A case study of Mellat Bank
}

\author{
Maryam Nadernezhad $^{\mathrm{a}^{*}}$ and Younos Vakilalroaia ${ }^{\mathrm{b}}$
}

${ }^{a}$ Master Student, Department of Management and Accounting, Semnan Branch, Islamic Azad University, Semnan, Iran

${ }^{b}$ Assistant Professor, Department of Management and Accounting, Semnan Branch, Islamic Azad University, Semnan, Iran

C H R O N I C LE

Article history:

Received May 10, 2013

Received in revised format

10 July 2013

Accepted 16 July 2013

Available online

July 192013

Keywords:

Brand equity

Brand awareness

Brand compatibility

Brand loyalty

Perceived quality

\section{A B S T R A C T}

\begin{abstract}
This study examines the influencing factors on brand equity in banking industry. The proposed study designs a questionnaire consists of 16 questions for measuring brand loyalty, brand awareness, brand compatibility and perceived quality in one of Iranian banks named Mellat Bank. Using a descriptive and non-experimental study, the proposed study gathers data and analyze them using t-student test. The results indicate that three components including brand loyalty, brand awareness and brand equity compatibility on brand equity of Mellat bank branches in Mazandaran province are in desirable level but the effect of perceived quality indicator on brand equity of Mellat Bank is not desirable. The study provides necessary suggestions to improve the quality of services for the proposed case study.
\end{abstract}

(C) 2013 Growing Science Ltd. All rights reserved.

\section{Introduction}

During the past few years, there has been growing trend on emerging new banks in Iran. Thanks to deregulation policy, Iranian people have more choices to do banking business and they could select banks whose services are more reliable (YL \& Lee, 2011). This increases competition in business and only banks with strong relationships with their customers may survive in long term. Banks need to develop new business services and measure customers' responses (Krishnan \& Hartline, 2001; Fahimi, 2006). Service quality is the key success for market development in banking industry (Javalgi \& Moberg, 2001). Aaker and Keller (1990) examined reactions to 20 brand extension concepts involving six well-known brand names. Their empirical investigation indicated that potentially negative associations can be neutralized by elaborating on the attributes of the brand extension than by reminding consumers of the positive associations with the original brand. Building a leadership brand plays an important role for the success of business owners (Aaker \& Joachimsthaler, 2009).

*Corresponding author. Tel: +98912 2316247

E-mail address: mnadernezhad@yahoo.com (M. Nadernezhad)

C) 2013 Growing Science Ltd. All rights reserved.

doi: $10.5267 / \mathrm{j} . \mathrm{ms} 1.2013 .07 .015$ 
Caceres and Paparoidamis (2007) considered service quality, relationship satisfaction, trust, commitment and business-to-business loyalty and reported that loyal customers are the most important assets of organizations. Chen (2001) examined the relationship between the characteristics of brand associations and brand equity based on free association and reported a positive relationship between these two components.

According to Caceres and Paparoidamis (2007) when management attitude is based on genuine conviction, there will be more chances for shared values and through shared values, there is a bigger likelihood of commitment, internal loyalty, clearer brand understanding, and importantly, consistent brand delivery across all stakeholders. Therefore, within a systems perspective, greater services brand consistency can be resulted. According to Elrod (2007) below the university level, there has been small amount of effort devoted in branding academia, namely academic departments. The lack of branding may substantially influence the perceptions that potential students and future employers of these students have only one of these academic units. The effect may be important for units where the fields of study represented by the department may be unclear, such as in the case of engineering management. However, even in the cases of better-understood fields of study, for instance, industrial engineering, the competition for students with other fields of study and within the field of study itself may force for better branding.

Nam et al. (2011) considered brand equity, brand loyalty and consumer satisfaction in other case study and reported that more satisfied customers will more likely become loyal customers as well. Odin et al. (2001) discussed different conceptual and operational aspects of brand loyalty. Robinson (2007) explained the role of customer loyalty in banking industry. Zeithaml (1988) investigated consumer perceptions of price, quality, and value: a means-end model and synthesis of evidence.

According to Faircloth et al. (2001) brand equity has been criticized by some for an alleged lack of managerial relevance. They performed a study which operationalized brand equity and empirically examined a conceptual model adapted from the work of Aaker (1991) and Keller (1993) considered the impact of brand attitude and brand image on brand equity. The results indicated that brand equity can be manipulated at the independent construct level by providing specific brand associations or signals to consumers and that these relationships could result in images and behaviors, which influence brand equity. Their results suggested that focusing on the constructs that create brand equity was more relevant to managers than trying to measure it as an aggregated financial performance outcome.

\section{The proposed study}

Based on the review material discussed earlier, the proposed study of this paper considers the following five hypotheses,

Main hypothesis: Different components of brand equity have various effects on proposed case study.

The main hypothesis of this survey consists of four other sub-hypotheses as follows,

1. The impact of "brand loyalty" is desirable on brand equity in Mellat Bank.

2. The impact of "brand awareness" is desirable on brand equity in Mellat Bank.

3. The impact of "perceived quality" is desirable on brand equity in Mellat Bank.

4. The impact of "brand compatibility" is desirable on brand equity in Mellat Bank.

To examine the proposed hypotheses of this survey, we have designed a questionnaire consists of 16 questions where four questions are assigned to each component of brand loyalty, brand awareness, perceived quality and brand compatibility. We have confirmed the content validity of the 
questionnaire by presenting it to 30 experts. The proposed study has been accomplished among 452 customers who received 2-15 million Rials loans from different branches of Mellat Bank in province of Mazandaran, Iran. Therefore, the sample size is calculated as follows,

$$
n=\frac{N \times z_{\alpha / 2}^{2} \times p \times q}{\varepsilon^{2} \times(N-1)+z_{\alpha / 2}^{2} \times p \times q},
$$

where $N$ is the population size, $p=1-q$ represents the yes/no categories, $z_{\alpha / 2}$ is CDF of normal distribution and finally $\varepsilon$ is the error term. Since we have $p=0.5, z_{\alpha / 2}=1.96$ and $N=452$, the number of sample size is calculated as $n=196$. The proposed study distributed 213 questionnaires and managed to collect 196 filled ones. Cronbach alpha (Cronbach, 1951; Zohori, 1999) has been calculated as 0.86, which is well above the minimum desirable limit and we can confirm the reliability of the questionnaire. We have performed the normality test on our data and confirmed that we can use parametric method for testing various hypotheses. Since all questions are designed in Likert scale from one to five, the null hypothesis for all questions is $\mu \leq 3$ and the alternative hypothesis is $\mu>3$. Fig. 1 demonstrates the structure of the proposed model.

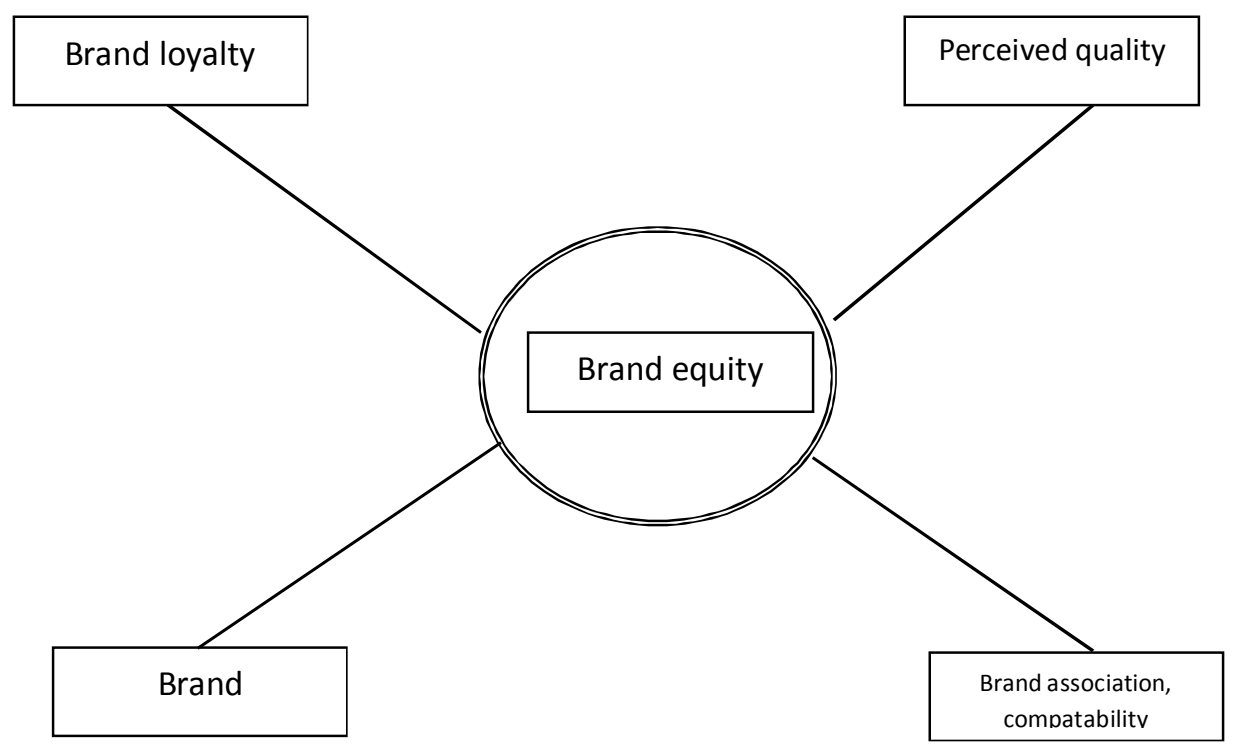

Fig. 1. The proposed study (Aaker, 1991)

\section{The results}

In this section, we present details of our finding on testing various hypotheses of this survey. In our experiment, there were about 196 samples where the mean and standard deviation of brand loyalty are equal to 2.0599 and 0.04553 , respectively. In addition, Table 1 demonstrates the results of tstudent test on this component.

Table 1

One Sample t-test for brand loyalty

\begin{tabular}{llllll}
$\mathrm{t}$ & $\mathrm{df}$ & $\begin{array}{c}\text { Bilateral } \\
\text { Significant level }\end{array}$ & $\begin{array}{c}\text { Difference } \\
\text { mean }\end{array}$ & \multicolumn{2}{c}{$\begin{array}{c}\text { Confidence distance 95\% of } \\
\text { differences } \\
\text { Lower limit }\end{array}$} \\
& & & Upper limit \\
\hline-9.665 & 195 & 0.00 & -0.4401 & -0.5298 & -0.3503 \\
\hline
\end{tabular}


Bases on the results of Table 1, we can reject the null hypothesis and conclude that brand loyalty is in desirable level according to our surveyed people. Similar results are obtained for brand awareness ( $\mathrm{t}-$ value $=-8.771, \mathrm{P}$-value $=0.001)$, brand association $(\mathrm{t}=5.802, \mathrm{P}$-value $=0.001)$ and brand equity $(\mathrm{t}=9.184$, $\mathrm{P}$-value $=0.001)$. However, the surveyed people did not confirm that perceived quality maintains at desirable level $(\mathrm{t}=2.168, \mathrm{P}$-value $=0.67)$.

We have also used Friedman test to rank the relative importance of each component of our survey and the results of our findings are summarized in Table 2 as follows,

\section{Table 2}

The summary of Friedman test on prioritizing factors influencing brand equity

\begin{tabular}{llc}
\hline Priority & Variable & Average rating \\
\hline 1 & Perceived quality & 17.31 \\
2 & Brand compatibility & 14.50 \\
3 & Brand awareness & 13.69 \\
4 & Brand loyalty & 13.13 \\
\hline
\end{tabular}

Based on the results of Table 2, perceived quality is number one priority followed by brand compatibility, brand awareness and brand loyalty.

\section{Discussion and conclusion}

Two kinds of conclusions could be used due to this study finding. At first, marketing managers should focus their efforts on brand loyalty; since if loyalty increases, it helps organization brand equity positively. Brand loyalty has several strategic benefits for organization like obtaining high market share and new customers, supporting brand expansion, reducing marketing costs and strengthening brand against competitive threats. Another point is the internal solidarity among structures, especially relationship between brand loyalty, brand awareness and perceived quality. According to Aaker (2009), while brand awareness is a familiar insight and a sign of commitment and survival, perceived quality is another tool, which acts differently. Consequently, we believe that by focusing on brand loyalty, managers should not ignore the effect of brand and perceived quality on brand equity.

Brand awareness is one of most powerful signs of powerful brand in customers' mind. This concept includes two concepts of brand identification and brand recalling. In order to build a powerful brand against competitors, in lower levels, consumers must have some sort of feeling on brand specifications. In addition, every brand, based on its nature, is going to induce special features in its audiences mind. Actually, these two levels comprise brand recognition levels. This means that when customer faces with a special feature, he/she must recall that brand.

Considerable point is that brand of most banks active in Iran banking industry is not associated with customers' special need and category. This issue is severely observable in governmental banks. But private banks meet this need to some extent. Customers cannot differentiate Mellat Bank services with other governmental banks like Tejarat Bank. Of course, this issue is highly resolved for Mellat bank customers but non-customers face with this problem. In relation to situation improvement of this variable in Mellat bank, it should be considered that brand awareness reflects edited brand identity in audiences' mind and it makes brand connected to product category or special need. For this reason, it should be considered that infrastructure of this variable and totally, infrastructure of brand creating strategies is brand identity document edition. The most important issue is that unfortunately in Iran, most organizations only regard visual aspect such as designing logo in order to establish brand identity and they ignore other aspects like picture type and their brand characteristics. In fact, some 
private banks in Iran could benefit this opportunity by considering this issue and they penetrated in market and make governmental banks in risk.

In this regard, behavioral insights are based on the purchase amount of a special brand and it links customer preferences and tastes of attitude insight. For every business, creating new customers will be expensive and of course, maintaining them could make costs more. However, existing customers is a tool for advertising brand and confidence for new customers. Customer based value depends on loyalty level and brand loyalty is directly affected by the level of satisfaction on trade name that is collected during time and it is affected by product quality. Brand loyalty is often showed as a symbol of brand equity because users with powerful brand equity are loyal to trade name. Best managers of trade name may hope to create loyal users.

This issue is a must for competition and today, many companies turn customer oriented quality into powerful strategic tool. They meet customer value and satisfaction via continuous and effective meeting of needs and preferences of customers about quality. For understanding perceived quality, it is beneficial to identify and to measure basic aspects, but perceived quality is a brief and universal structure by itself.

Compatibilities and associations introduce a basis to buy decisions for brand loyalty and it is a creator of value for company and its customers. These benefits are listed as: helping information processing and renewing, differentiating for brand, making reason and logic for purchase, creating positive feelings and attitudes and supporting development and promotion. Brand association is obtained for users from two sources. One before usage relationships about trade name, trade name manager should provide main resource from brand association. Another one is that brand can create and develop new collection of associations. Brand association is a center for brand equity because it is a key component for competitive advantage. Brand awareness is a necessary but not sufficient condition for creating brand equity. In addition, these associations make brand mind an image, which could be an identity source for brand identity.

If Mellat bank is to induce especial characteristics in minds, it needs to edit long-term strategies. At the beginning of this, brand identity should be edited and all brand aspects should be considered. In practice, this document plays a police role and makes some limitations on marketing activities and based on that, it opens new windows for bank. For example, in this case, Mellat Bank advertisement is not effective through each medium. In addition, maybe frequent references of customers to branches of this bank make minds destroy. However, bank can use consistent style of promotions and Mellat bank must do different actions to improve brand recalling situation. First, management must establish its suitable brand identity according to existing conditions and next step is to promote the plan.

If bank advertisement can convey brand identity characteristics consistently, after a while an image of these features will penetrate in mind. If bank can deliver its characteristics in operation and in its branches and helps its customers understand about their efforts, then these consistent characteristics will be consisted and consolidated. In addition, branch appearance as non-customers have undesirable mind will be highly effective in changing imagination of this bank.

Finally, based on the results of research, practical suggestions for improving brand equity and brand product management is offered to marketing management. First, bank must design and implement customer relationship management and customer knowledge management to obtain customer's knowledge about his/her preferences towards a brand and customer preference analysis through data mining techniques in order to increase the value of brand products from the perspective of the customer. Second, bank needs to implement educational programs and empower staff as internal 
customers, improve formal and informal communication to transfer goals, values and aspirations of the company, talent management, job enrichment to improve staff understanding of brand products through creativity and innovation.

\section{References}

Aaker, D. A., \& Joachimsthaler, E. (2009). Brand leadership: Building assets in an information economy. SimonandSchuster.com.

Aaker, D. A., \& Keller, K. L. (1990). Consumer evaluations of brand extensions. The Journal of Marketing, 54(1), 27-41.

Aaker, D. A. (2009). Managing brand equity. SimonandSchuster.com.

Abbott, G. N., White, F. A., \& Charles, M. A. (2005). Linking values and organizational commitment: A correlational and experimental investigation in two organizations. Journal of occupational and organizational psychology,78(4), 531-551.

Caceres, R. C., \& Paparoidamis, N. G. (2007). Service quality, relationship satisfaction, trust, commitment and business-to-business loyalty. European Journal of Marketing, 41(7/8), 836-867.

Chen, A. C. H. (2001). Using free association to examine the relationship between the characteristics of brand associations and brand equity. Journal of Product \& Brand Management, 10(7), 439-451.

Cronbach, L. J. (1951). Coefficient alpha and the internal structure of tests. Psychometrika, 16(3), 297-334.

De Chernatony, L., \& Segal-Horn, S. (2003). The criteria for successful services brands. European Journal of Marketing, 37(7/8), 1095-1118.

Elrod, C. (2007). The development and application of a systematic approach to evaluating an academic department's brand meaning.

Fahimi, A.H. (2006). Factors affecting customer selection and loyalty in banking: a study on Mellat bank depositors. Tehran University School of Management.

Faircloth, J. B., Capella, L. M., \& Alford, B. L. (2001). The effect of brand attitude and brand image on brand equity. Journal of Marketing Theory and Practice, 61-75.

Kayaman, R., \& Arasli, H. (2007). Customer based brand equity: evidence from the hotel industry. Managing Service Quality, 17(1), 92-109.

Keller, K. L. (2002). Branding and brand equity. Handbook of marketing, 151-178.

Keller, K. L., Parameswaran, M. G., \& Jacob, I. (2011). Strategic brand management: Building, measuring, and managing brand equity. Pearson Education India.

Kotler, P. (1991). Marketing Management: Analysis, Planning, Implementation, and Control-7/E.

Krishnan, B. C., \& Hartline, M. D. (2001). Brand equity: is it more important in services?. Journal of Services Marketing, 15(5), 328-342.

Javalgi, R. R. G., \& Moberg, C. R. (1997). Service loyalty: implications for service providers. Journal of Services Marketing, 11(3), 165-179.

Nam, J., Ekinci, Y., \& Whyatt, G. (2011). Brand equity, brand loyalty and consumer satisfaction. Annals of Tourism Research, 38(3), 1009-1030.

Odin, Y., Odin, N., \& Valette-Florence, P. (2001). Conceptual and operational aspects of brand loyalty: an empirical investigation. Journal of Business Research, 53(2), 75-84.

Robinson, K. (2007). Retail banking: The pros and cons of global branding. The Banker, 1.

Washburn, J. H., \& Plank, R. E. (2002). Measuring brand equity: an evaluation of a consumer-based brand equity scale. Journal of Marketing Theory and Practice, 46-62.

YL, C. F., \& Lee, G. C. (2011). Customer-Based Brand Equity: A Literature Review. Journal of Arts Science \& Commerce ISSN, 2229(4686), 4686.

Zeithaml, V. A. (1988). Consumer perceptions of price, quality, and value: a means-end model and synthesis of evidence. The Journal of Marketing, 2-22.

Zohori, G. (1999). Research methods application in social sciences in management, Tehran: Mir Publishers. 